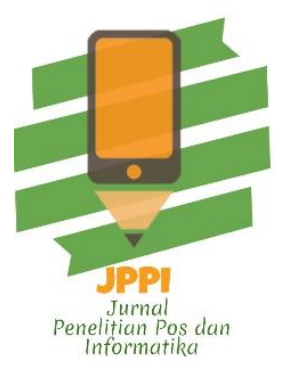

\title{
INFORMATION TECHNOLOGY STRATEGIC PLAN USING WARD AND PEPPARD METHOD (A CASE STUDY OF THE DIPLOMA PROGRAM OF IPB UNIVERSITY)
}

\author{
PERENCANAAN STRATEGIS TEKNOLOGI INFORMASI \\ MENGGUNAKAN METODE WARD AND PEPPARD (STUDI KASUS \\ PROGRAM DIPLOMA INSTITUT PERTANIAN BOGOR)
}

Ringga Gilang Baskoro', Yani Nurhadryani², Bagus P Purwanto ${ }^{3}$

${ }^{1}$ Mahasiswa Pasca Sarjana Ilmu Komputer IPB

${ }^{2}$ Departemen Ilmu Komputer FMIPA IPB

${ }^{3}$ Program Diploma IPB ringgagbaskoro@gmail.com

Naskah Diterima: 3 Juli 2018; Direvisi : 4 Mei 2018 ; Disetujui : 12 Juli 2019

\begin{abstract}
Te Vocational School of IPB University has utilized information technology (IT) to support its business process. The problem is the existing information technology has not been effective in supporting the main business process. Improvements are needed for the components of data processing and information systems. Applying information technology aligned with the needs of business processes requires a plan to minimize the occurrence of failure in the implementation phase. IT strategic plan plays important role as guidelines and directions for IT operation in an organization. The stages of IT strategic plan are performed based on Ward and Peppard framework. IT strategic plan formulated in this study consists of some components such as application portfolio, IT management strategy, and IT architecture recommended for the Vocational School of IPB University .
\end{abstract}

Keywords: information technology, information system, strategic plan, vocational college, Ward and Peppard. 


\section{INTRODUCTION}

The role of information technology (IT) is currently no longer limited to the support elements of business process, rather, it began to swift functions as an enabler for various efforts of quality, effectiveness, efficiency, and accountability improvements or enabler for the realization of the institutions' objectives. IT makes business process more effective in accomplishing missions and efficient in managing and using resources. IT also support the realization of institutions' vision (Oktavia et al. 2013). Ministry of Education and Culture data in 2018 ( http://reference.data.kemdikbud.go.id/) shows that there are 2,776 higher educational institutions in Indonesia, both public and private. The data records that approximately 2,194 of the total educational institutions already utilize information technology, one of which in the form of a university website to support their business processes. The Webometrics (a ranking system for the world's universities based on their online publication through their websites) ranks IPB on the 4th position of Indonesian universities (http: //www.webometrics.info/en/Asia/indonesia). This indicates that IPB had been appropriately utilizing information technology to support its business activities. In this regards, the Diploma Program, as one of the working units of IPB University, plays a significant role in improving the quality of IPB university for one of the assessment criteria of the webometrics is how universities utilize online media to support their existing businesses process. In 2016, IPB university, through the DIDSI, has carried out evaluation of the performance of the website of the 12 implementation units of IPB university which consists of 9 faculties, one graduate program, one school of business, and one diploma program. Utilization performance of IPB University Diploma Program's website was weighted 30.53 out of 100 points, placing it on the 12th position with the category of less performing website. This data has motivated the IPB University Diploma Program to improve the use of IT in supporting its business processes.

IPB University Diploma Program is one of IPB University's implementation units providing 18 programs of expertise. The Human Resources and Academic unit data of 2018 states that currently the IPB University Diploma Program has 6,767 active students, with 114 lecturers and 90 educational personnel. As an educational institution, the IPB University Diploma Program performs many business processes in its daily activities. The business process ranges from promotions to feedback gatherings from alumni and alumni users. Business process also covers the supporting of academic processes including management of assets, management of nonacademic student activities, management of supporting facilities such as the library, clinic laboratory, and others. The evaluation of TESCA 2011 questionnaires resulted in early evaluation result of 31.9 percent which put the IPB University Diploma Program at the pratama level. At this level, IPB University Diploma Program has been able to provide value added to the process of education and learning through the use of IT, although its performance may have not been able to meet the expectation of its stakeholders.

Currently the IPB University Diploma Program has several information systems used to 
support its business process, one of which in the implementation of the academic-related affairs. However, the implementation process is faced with many challenges, among other, data and information that is processed and produced from the existing systems are still scattered on the scope of the managers' internal unit. This condition hampered the process of information dissemination between units and stakeholders. The IT needs to be designed to be aligned with the organization's business process, this is a challenge that must be faced and supported by all parties within an institution (Jonkers et al. 2006, Chan and Reich 2007). This study generally uses the fishbone analysis to recognize and find out the problems occurred (Figure 1) .

This study aims to compile IT strategic planning documents for the IPB University Diploma Program with outputs in the form of proposed portfolio applications, IT infrastructure design, and IT management strategies. This document will be used as a guideline in developing IT that is aligned and supports the achievement of the objectives of the IPB University Diploma Program. This study on IT strategic plan for IPB
University Diploma Program is limited to the aspect that is associated with the business process and business process supporting aspects in the IPB University Diploma Program in accordance with its Standard Operating Procedures SOP). In the preparation of the strategic plan, the frameworks of Ward and Peppard (Ward and Peppard 2002) strategic planning is used.

\section{METHODOLOGY}

This study uses the framework of Ward and Peppard IT strategic planning (Ward dan Peppard 2002) which comprises the following phases:

\section{Internal Business Environment Analysis}

This phase indentifies internal aspects to map the current organization and business strategy. The followings are matters related with the internal business environment analysis:

IPB University Diploma Program's Vision, Mission, and Business Strategy SW (Strength, Weakness) analysis

The analysis of IPB University Diploma Program's vision, mission, and goals is the initial step of strategic planning.

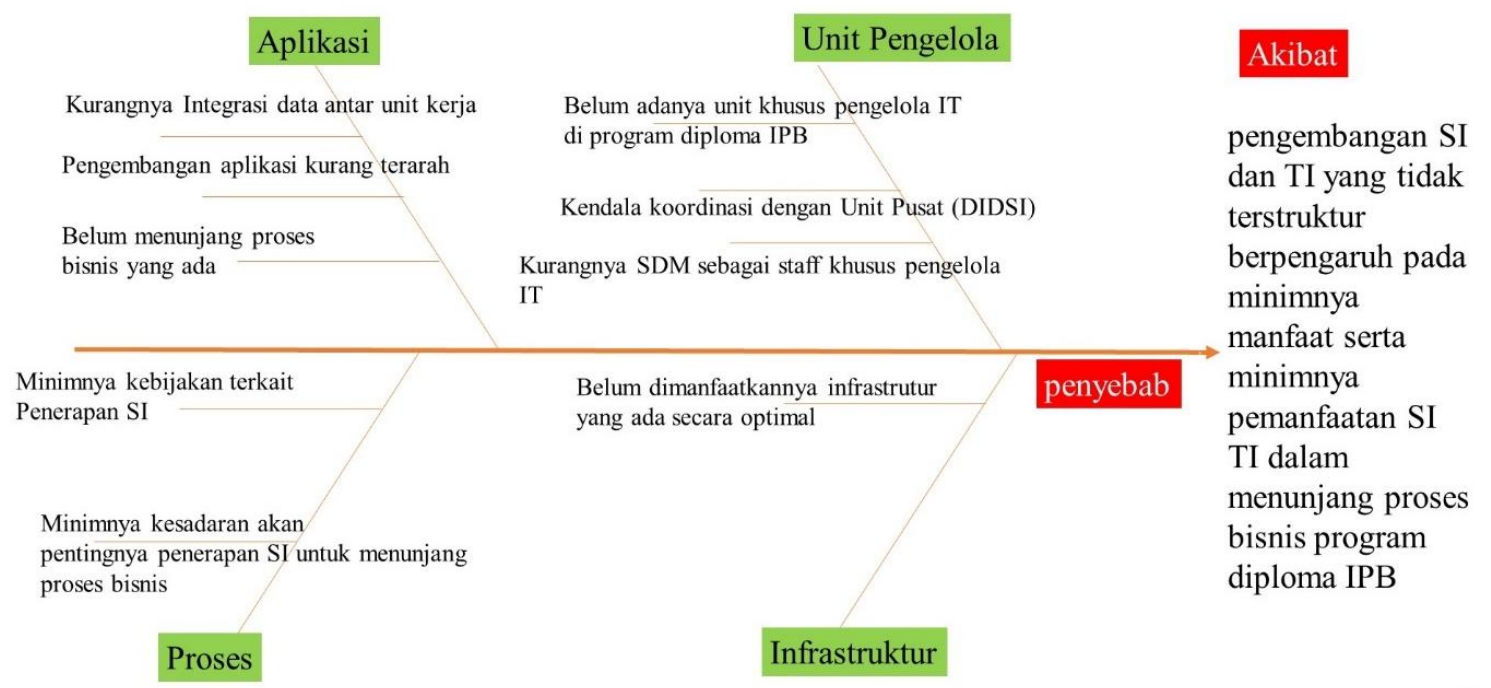

Gambar 1. Analisis fishbone permasalahan TI Program Diploma IPB 
Internal business environment analysis using the analysis component of IPB University Diploma Program's strengths and weaknesses.

\section{Value Chain Analysis}

This concept was introduced by Michael Porter (1998), it depicts the organization's entire activities to support its product, both internal or external, and reveals the organization's competitive advantages or disadvantages. The analysis is carried out to map the entire business process that occurs in the IPB University Diploma Program into two categories of activity, namely the primary and support activities.

\section{Critical Success Factor (CSF)}

The CSF is aimed to have clearer interpretation of objects to determine which activities must be carried out and what information is needed (Ward and Peppard, 2002). CSF analysis is very useful when used in parallel with value chain analysis in identifying the most critical processes, as well as focusing on achieving goals through the most appropriate activities to be carried out (Zhang et al. 2013).

\section{External Business Environment Analysis}

In this phase, analysis is carried out regarding the organization's external factors which have potential influence on the organization's strategy using the OT (Opportunity, Threat) analysis.

\section{Internal IT Environment Analysis}

In this phase, analysis is carried out on the current conditions of the IT conditions used in

\begin{tabular}{|c|c|c|c|c|}
\hline \multirow{6}{*}{ 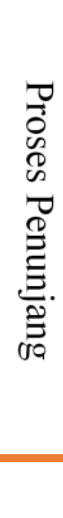 } & \multicolumn{4}{|c|}{ (VC8) Pengelolaan administrasi keuangan } \\
\hline & \multicolumn{4}{|c|}{ (VC9) Pengelolaan administrasi akademik } \\
\hline & \multicolumn{4}{|c|}{ (VC10) Pengelolaan SDM } \\
\hline & \multicolumn{4}{|c|}{ (VC11) Pengelolaan kegiatan kemahasiswaan } \\
\hline & \multicolumn{4}{|c|}{ (VC12) Pengelolaan sarana dan prasarana } \\
\hline & \multicolumn{4}{|c|}{ (VC13) Teknologi dan infrastruktur } \\
\hline \multirow{5}{*}{ 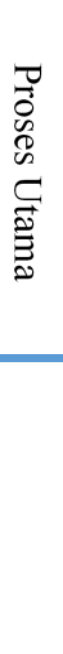 } & $\begin{array}{l}\text { (VC1) } \\
\text { Kegiatan } \\
\text { promosi }\end{array}$ & $\begin{array}{l}\text { (VC3) } \\
\text { Proses belajar } \\
\text { mengajar }\end{array}$ & $\begin{array}{l}\text { (VC6) } \\
\text { Kelulusan } \\
\text { Dan }\end{array}$ & $\begin{array}{c}\text { (VC7) } \\
\text { Pelayanan Kepada } \\
\text { stakeholder }\end{array}$ \\
\hline & \multirow{2}{*}{$\begin{array}{l}\text { (VC2) } \\
\text { Penerimaan } \\
\text { mahasiswa } \\
\text { baru }\end{array}$} & $\begin{array}{l}\text { (VC4) Riset dan } \\
\text { pengembangan }\end{array}$ & & \\
\hline & & $\begin{array}{c}\text { (VC5) Pegabdian } \\
\text { masyarakat }\end{array}$ & & \\
\hline & \multicolumn{4}{|c|}{ Gambar 2. Value chain Program Diploma IPB } \\
\hline & & Sumber: Hasil an & & \\
\hline
\end{tabular}


supporting IPB University Diploma Program operational activities. Results of this analysis are IT organizational structure and resources, IPB University Diploma Program's portfolio application which is presented in McFarlab Strategic Grid, business process analysis to determine the information needed in IPB University Diploma program's business process, and analysis of the organization's IT infrastructures (hardware, software, network).

\section{External IT Environment Analysis}

This phase indentifies the current IT development and future trends. The technology used by customers (students candidates, students, public, related institutions, business, and industries cooperating with IPB University Diploma Program), suppliers (lecturers), and competitors (similar educational institutions).

\section{Recommendations of Strategy}

This study suggests a number of recommendations. First, future information technology portfolio which is aligned with the needs of IPB University Diploma Program. The future portfolio reveals the investment priorities recommended to be made by the organization, as well as the applications that are potentially useful in the future for the organization. Second, IT infrastructures to support the future application portfolio. Third, IT management policies (resources, infrastructures, security).

\section{RESULTS AND DISCUSSIONS}

\section{Internal Business Environment Analysis}

Value Chain Analysis

The value chain analysis results are obtained by referring to standard operational procedures that have been determined in the diploma program (SOP of Diploma IPB 2014). The 22 existing business processes in IPB University Diploma Program are divided into two categories, namely the main processes and support processes, which are described in the diagram value chain (Figure 3).

\section{Critical Success Factor (CSF)}

IPB University Diploma Program already has its documents of Internal Quality Assurance System and Quality Standards for Diploma Education Program which is established in the Regulation of the IPB Rector No. 06/IT3/DT/2013. The Quality Standards applied for IPB University Diploma Program is the critical factor to measure the successful operation of the program. IPB's quality standards refer to those standards and parameters used by the National Accreditation Agency for Higher Education (BAN-PT), the Education Quality Standards (EQS), and Quality Assurance System in Higher Education (SPMPT). In order to apply the SMM ISO 9001:2008, the IPB University Diploma Program has established 52 quality targets which include targets and measures of success for every target (SPMI Diploma IPB 2013).

\section{SWOT Analysis}

Based on the results of observations on the business processes conducted by each working units and results of in-depth interviews with each working units, the factors of strength, weaknesses, opportunities, and threats of the IPB University Diploma Program were identified (Table 1). 
Table 1. SWOT Analysis of the IPB Univ. Diploma Program's IT

\begin{tabular}{|c|c|}
\hline $\begin{array}{l}\text { Strength-opportunity } \\
\text { strategies }\end{array}$ & $\begin{array}{l}\text { Strength-thread } \\
\text { strategies }\end{array}$ \\
\hline 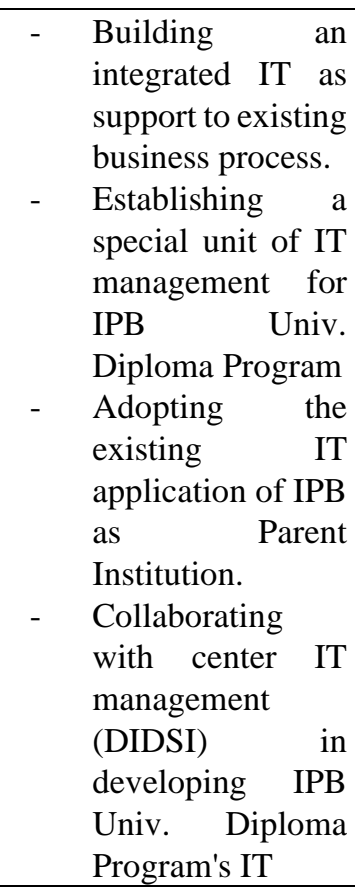 & 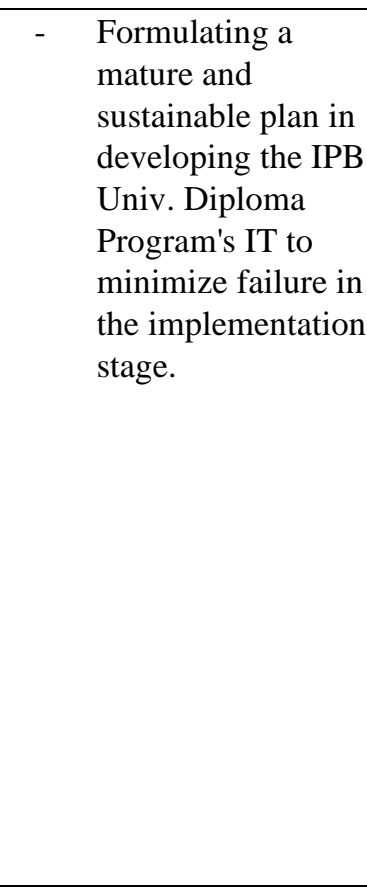 \\
\hline $\begin{array}{l}\text { Weakness-opportunity } \\
\text { strategies }\end{array}$ & $\begin{array}{l}\text { Weakness-threats } \\
\text { strategies }\end{array}$ \\
\hline 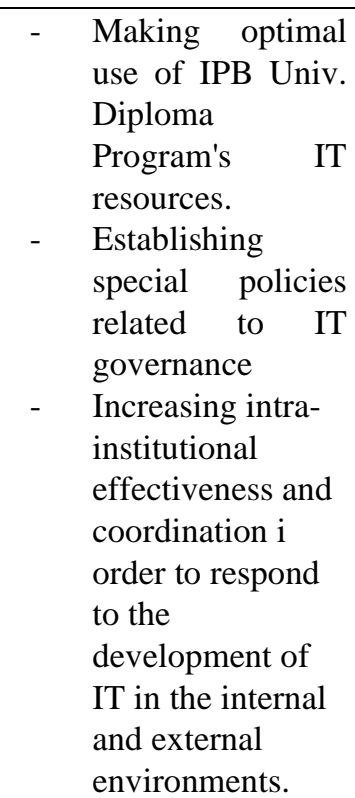 & $\begin{array}{l}\text { - } \text { Overcoming } \\
\text { weaknesses in } \\
\text { coordination and } \\
\text { integration } \\
\text { mechanism of data } \\
\text { and information }\end{array}$ \\
\hline
\end{tabular}

\section{Analysis of the IT conditions of IPB University} Diploma Program's

Results of the analysis on the information systems currently owned by IPB University Diploma Program is summarized in the application portfolio using McFarlan Strategic Grid (Table 2).

Table 2. IPB Univ. Diploma Program's Current Program Portfolio

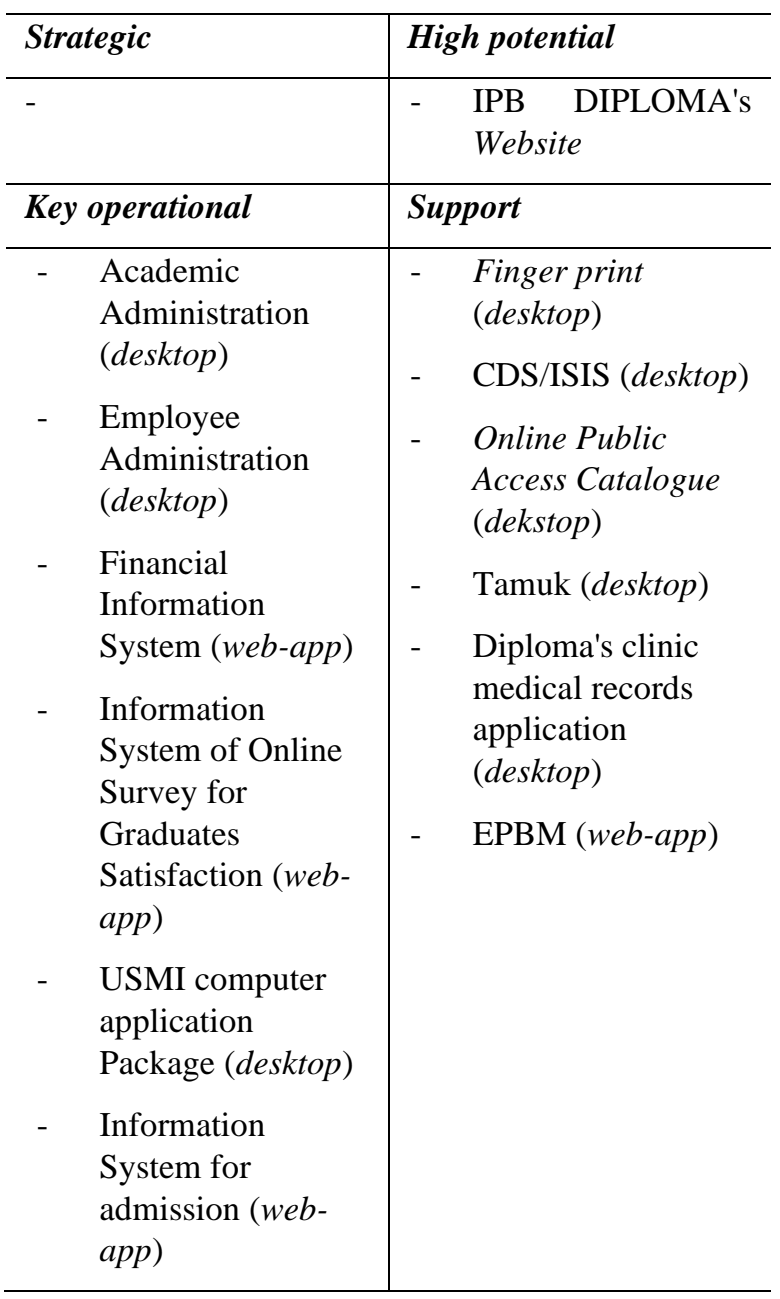

Most of the current existing applications were those developed in the beginning of the establishment of IPB University Diploma Program which are aimed to support its main process of academic activities. the current existing applications have not been optimally integrated. Each application generate separate information which are not yet connected. The 13 applications which are currently applied comprise of 8 desktop applications and 5 web-based applications. A number of computers are used as servers and function as storage media for data generated from 
applications used. the server computers were located in each existing working units, namely academic, library, clinic, and computer laboratory. Current conditions has caused problems in related units and related stakeholders who need data or information.

Table 3. Application specifications of IPB Univ. Diploma Program

\begin{tabular}{|c|c|}
\hline Application name & Information \\
\hline $\begin{array}{l}\text { Academic } \\
\text { Administration }\end{array}$ & $\begin{array}{ll}- & \text { Platform windows } \\
- & \text { desktop applications } \\
- & \text { LAN network } \\
- & \text { User: academic staff and } \\
& \text { data } \\
\text { - } & \text { academic administration } \\
& \text { data management } \\
& \text { function }\end{array}$ \\
\hline $\begin{array}{l}\text { Employee } \\
\text { Administration }\end{array}$ & $\begin{array}{ll}- & \text { Platform windows } \\
- & \text { desktop applications } \\
- & \text { LAN network } \\
- & \text { User: } H \& R \text { staff } \\
& \text { members } \\
- & \text { employee data } \\
& \text { management function }\end{array}$ \\
\hline $\begin{array}{l}\text { Information System } \\
\text { for Graduates } \\
\text { Satisfaction Survey }\end{array}$ & $\begin{array}{ll}- & \text { Web-based } \\
- & \text { Link http://skw.ipb.ac.id/ } \\
- & \text { Internet network } \\
- & \text { User: alumni } \\
- & \text { Graduates satisfactory } \\
& \text { survey function } \\
- & \text { IPB University Quality } \\
\text { management office } \\
\text { managers. }\end{array}$ \\
\hline $\begin{array}{l}\text { USMI Computer } \\
\text { application package } \\
\text { (PAKU) }\end{array}$ & $\begin{array}{ll}\text { - } & \text { Platform windows } \\
\text { - } & \text { desktop application } \\
\text { - } & \text { LAN network } \\
\text { - } & \text { User: Data staff member } \\
\text { - } & \text { IPB univ. Diploma } \\
& \text { program student } \\
\text { candidate data } \\
\text { management function }\end{array}$ \\
\hline Finger print & $\begin{array}{ll}\text { - } & \text { Platform windows } \\
\text { - } & \text { desktop application } \\
\text { - } & \text { LAN and internet } \\
& \text { networks } \\
\text { - } & \text { User: employees of IPB } \\
& \text { Univ. Diploma Program } \\
\text { - } & \text { attendance monitoring } \\
& \text { function }\end{array}$ \\
\hline CDS/ISIS & $\begin{array}{ll}- & \text { Platform windows } \\
- & \text { desktop application } \\
- & \text { LAN network } \\
- & \text { User; library staff } \\
& \text { members }\end{array}$ \\
\hline
\end{tabular}

\begin{tabular}{|c|c|}
\hline & $\begin{array}{l}\text { - library data management } \\
\text { function }\end{array}$ \\
\hline $\begin{array}{l}\text { Online Public Access } \\
\text { Catalogue }\end{array}$ & $\begin{array}{ll}- & \text { Platform windows } \\
- & \text { desktop application } \\
- & \text { LAN network } \\
- & \text { User; } \text { library visitor } \\
- & \text { library data search } \\
& \text { function }\end{array}$ \\
\hline Tamuk & $\begin{array}{ll} & \text { Platform windows } \\
\text { - } & \text { desktop application } \\
\text { - } & \text { LAN network } \\
\text { - } & \text { User: library visitor } \\
\text { - } & \text { Guest book function } \\
\end{array}$ \\
\hline $\begin{array}{l}\text { IPB Univ. Diploma } \\
\text { Program's clinic } \\
\text { medical record } \\
\text { application }\end{array}$ & $\begin{array}{ll}- & \text { Platform windows } \\
- & \text { desktop application } \\
- & \text { User: clinic staff } \\
& \text { members } \\
- & \text { clinic patient data } \\
& \text { management function } \\
\end{array}$ \\
\hline Financial application & $\begin{array}{ll}- & \text { Web-based } \\
- & \text { internet network } \\
- & \text { User: financial staff } \\
& \text { members } \\
\text { - } & \text { IPB Univ. Diploma } \\
& \text { Program financial data } \\
& \text { reporting function to } \\
& \text { central IPB } \\
\end{array}$ \\
\hline EPBM application & $\begin{array}{ll}- & \text { Web-based } \\
- & \text { Link http://skw.ipb.ac.id/ } \\
- & \text { internet network } \\
- & \text { User: students } \\
- & \text { learning and teaching } \\
& \text { evaluation function } \\
- & \text { IPB quality management } \\
& \text { office managers }\end{array}$ \\
\hline $\begin{array}{l}\text { Application for } \\
\text { admission }\end{array}$ & $\begin{array}{ll}- & \text { Web-based } \\
- & \text { Link http://skw.ipb.ac.id/ } \\
- & \text { internet ntework } \\
- & \text { User; student candidates } \\
- & \text { admission process } \\
& \text { function }\end{array}$ \\
\hline
\end{tabular}

In terms of IT infrastructure availability, the diploma program already has IT infrastructure and support facilities which are categorized as: computers, servers, and internet. the diploma program has approximately 500 computer units which are actively used for computer laboratory, lecturers, employees, as well as top managers. According to data from Directorate of Data Integration and Information System (DIDSI), currently all IPB's intranet are using the fiber optic (FO) technology, twisted-pair, and wireless local area network (WLAN). IPB has a cisco 
technology-based FO for its core link and distribution which has been utilized for various other technologies including intranet and Voice over internet protocol (VoIP). FO technology is also used for the interconnection in IPB campuses located outside Darmaga, namely Baranangsiang Campus, Cilibende Campus (Diploma), and Gunung Gede Campus (MB). Figure 4 displays the network typology of the IPB University Diploma Program which is designed based on direct observation. the bandwidth allocation for the IPB University Diploma Program is $400 \mathrm{Mbps}$ with 200Mbps uploads and 200Mbps downloads. Most of the computer facilities in the diploma program have been connected to LAN networks, especially computers located in the computer laboratory.

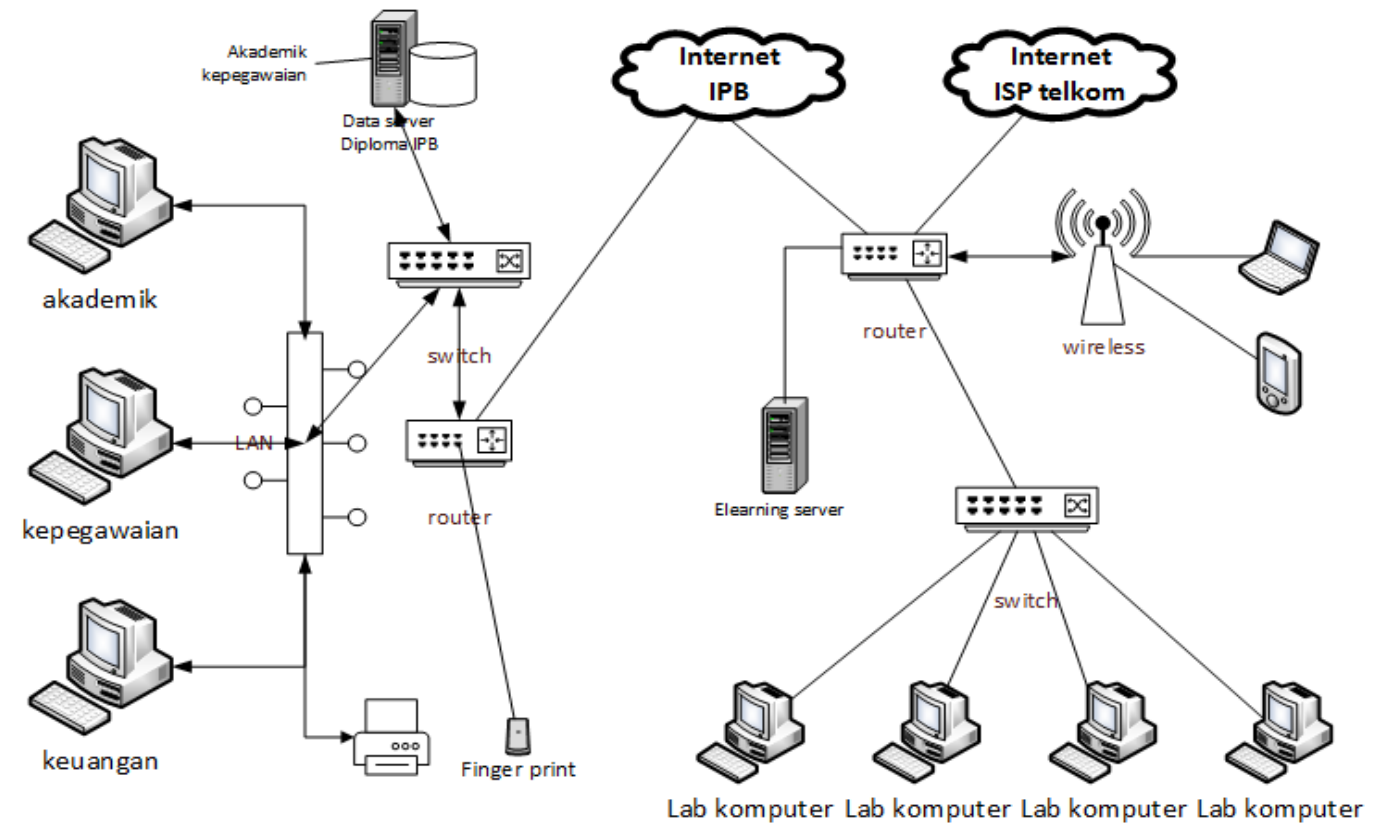

Figure 3. Current architecture of network of IPB Univ. Diploma Program Source: Analysis results

\section{External IT Development Analysis}

There has been a very rapid development of the current trends of technology. Various fields, including education, government, or corporations strive to improve their respective services quality by utilizing information technology. There are various solutions that may be used by institutions in implementing information technology, starting from developing the system from zero to collaborating with vendors of information technology service providers appropriate to the needs of related institutions. Each option comes with its advantages and disadvantages. Development of applications from zero requires a very mature planning including on long-term planning for support infrastructures in order to be able to support the development of a sustainable system. in addition, competent experts are needed to develop the planned system.

Another trend currently developing is that there is a multitude of business which prefer to partner with third parties (IT services provider vendors) to manage the information systems they use by utilizing the cloud computing technology 
rather that develop their own desired information technology. Ease of implementation and maintenance as well as guarantee of data security offered become main points of considerations (Maimunah 2012).

\section{IT Strategy Recommendations}

\section{Data and Information Architecture}

There is a significant need for data and

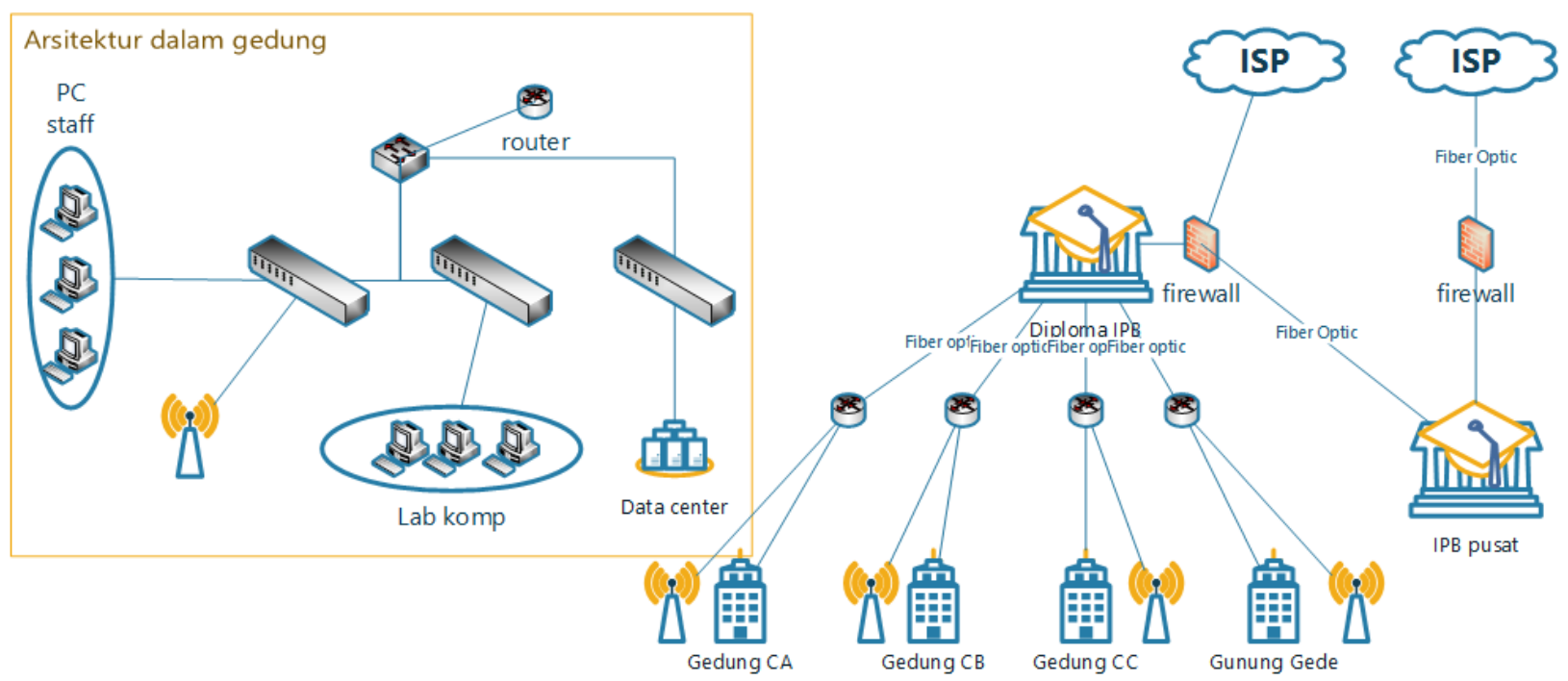

Gambar 4. Recommendation for network architecture for IPB Univ. Diploma Program 


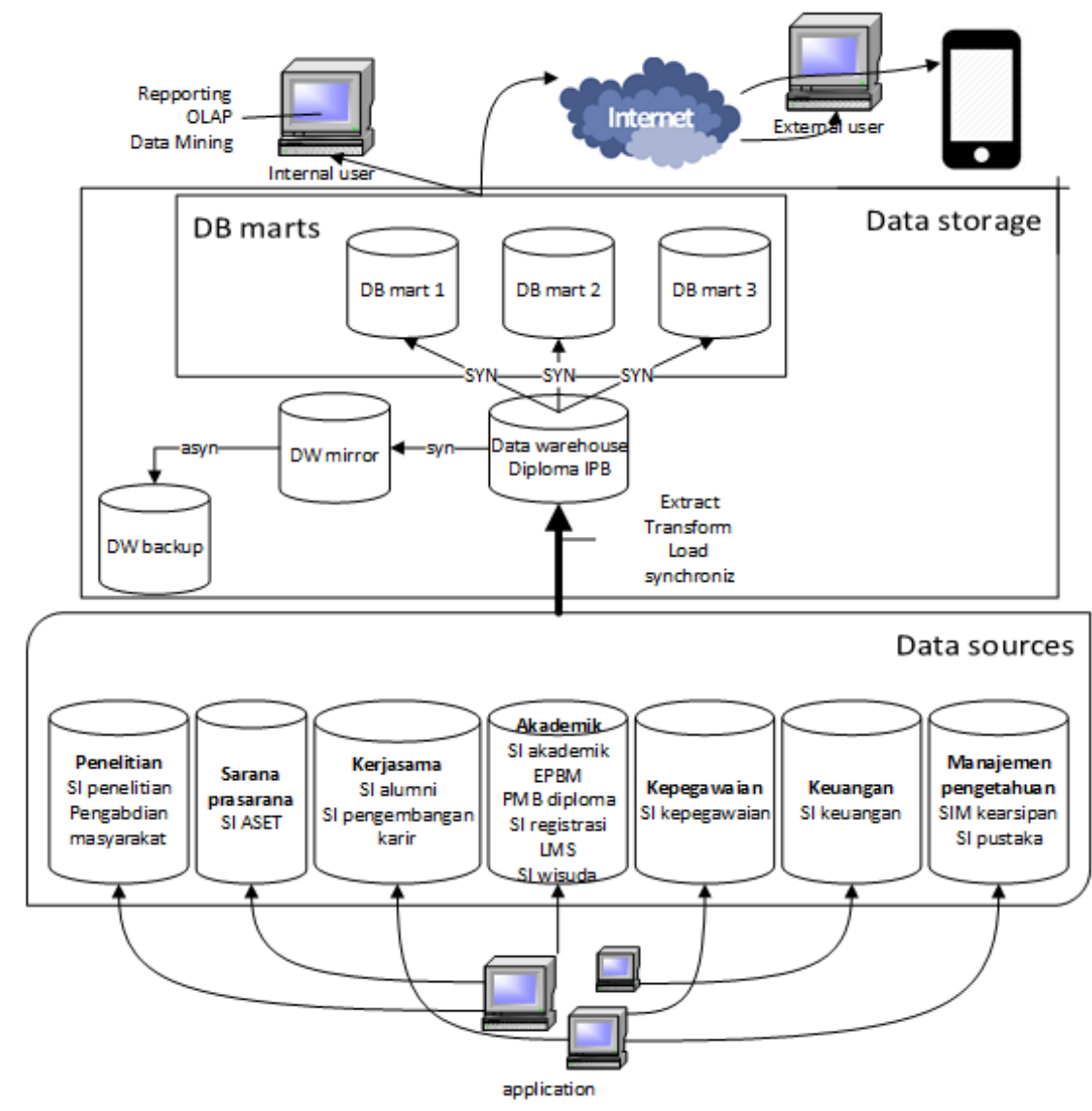

Gambar 5. Recommendation for information and data architecture for IPB Univ. Diploma Program Application Portfolio analysis gap can be seen in Table 5.

Based on the results of the analysis of the information needed, this study recommends information system solution to be developed in IPB University Diploma Program as shown in Table 3. Not all applications are included in the table due to limited space. Applications in the key operational quadrant will become the main priority for implementation stage. The applications are identified as priority since they play important roles in the continuity of business process in the organization.

The application portfolio (Table 4) reveals an analysis gap between the current information system and the information system in the suggested organization's strategic plan. The
Table 4. Recommendation o application portfolio for IPB University Diploma Program

\begin{tabular}{|c|c|}
\hline Strategic & High potential \\
\hline Executive IS (web-app) & $\begin{array}{l}\text { - IPB DIPLOMA } \\
\text { website } \\
\text { - } \text { collaboration IS }\end{array}$ \\
\hline Key operational & Support \\
\hline $\begin{array}{l}\text { - Academic administration } \\
\text { - Employee administration } \\
\text { - Financial information system } \\
\text { - Admission Information } \\
\text { System } \\
\text { - Registration IS (new and old } \\
\text { students) } \\
\text { - Graduation IS } \\
\text { - Administrative documents } \\
\text { management and archive IS }\end{array}$ & $\begin{array}{ll}\text { - } & \text { Alumni association } \\
& \text { forum IS } \\
\text { - } & \text { Carrier } \\
& \text { development IS } \\
\text { - } & \text { Research and } \\
& \text { development IS } \\
\text { - } & \text { Facilities and } \\
& \text { Infrastructures IS } \\
\text { - } & \text { Scholarship IS } \\
\text { - } & \text { EPBM } \\
\text { - } & \text { Library IS } \\
\end{array}$ \\
\hline
\end{tabular}




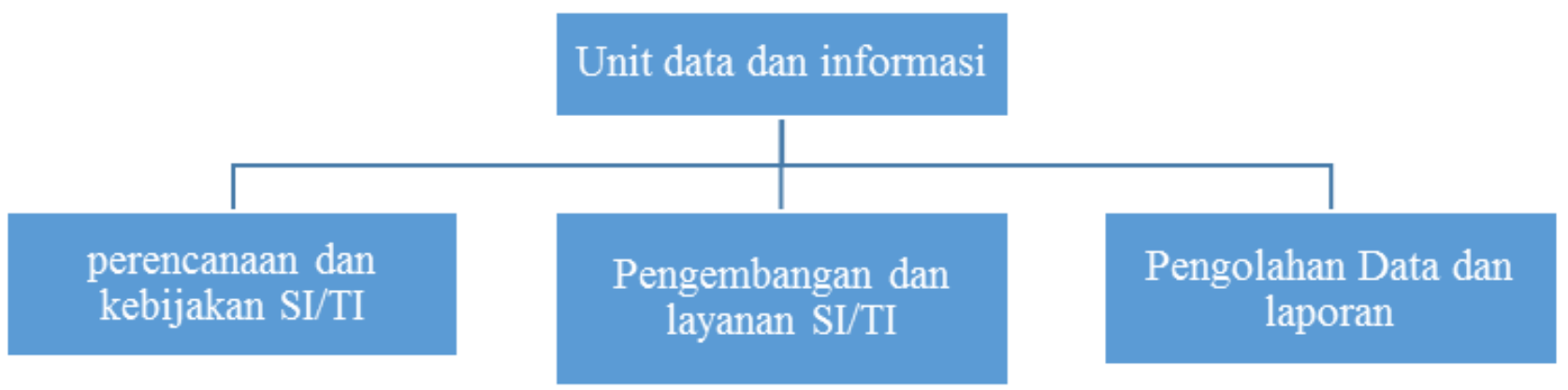

Gambar 6. Recommendation of IT organizational structure of IPB Univ. Diploma Program

Tabel 5. Alaysis Gap of application portfolio

Optimized Developed Retained Replaced

\section{Academic Applications group}

IPB Univ. Diploma Program Academic IS

IPB Univ. Diploma Program Registration and

Admissions Test IS

IPB Univ. Diploma Program Student Registration IS

Graduation IS

EPBM

\section{Employment application group}

Employee administration IS

\section{Financial application group}

Financial IS

\section{Facilities and Infrastructure application group}

Facilities and infrastructure IS

Library IS

\section{Research and Community Service application group}

Research and Community Service IS

Administrative Document Management and Archive IS

Executive IS

\section{Collaboration application group}

\section{Alumni IS \\ Carrie Development IS \\ Scholarship IS}

\section{Total}

\section{IT Management Strategy}

From the IPB University Diploma Program IT strategy identification phase, a number of strategies are recommended to be implemented including designing IT development vision and missions, IT policies planning, as well as IS and IT organization structure formulation. In principle,

$\begin{array}{ll}\sqrt{ } & \\ & \sqrt{ } \\ & \sqrt{ } \\ & \sqrt{ }\end{array}$

$\sqrt{10}$

$\sqrt{ }$

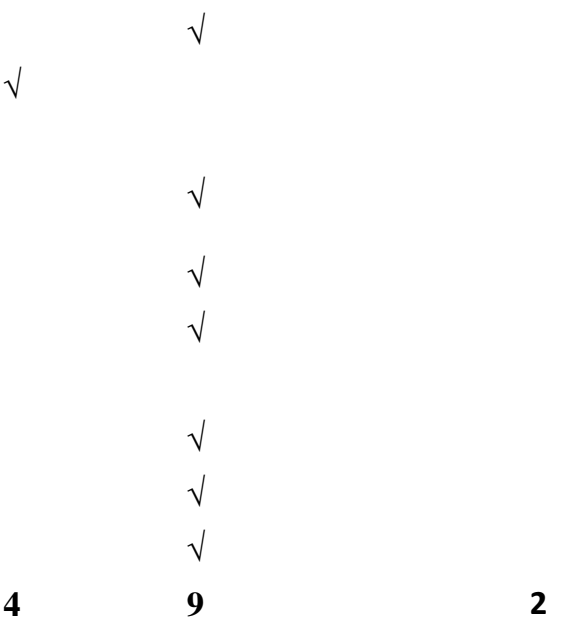

the IT vision and missions must be aligned with the vision and missions of IPB University Diploma Program. in order to support the achievement of the IT implementation vision and missions, a special unit of information management need to be established to assume the tasks of material collection, research, 
implementation, and evaluation of management of system, network, sites, information presentation, and periodical reports on the implementations of tasks. The unit is expected to be able to increase the IT development management and coordination in IPB University Diploma Program in the determination of policy and coordination related to IT development and management in IPB University Diploma Program. Figure 7 shows the recommended structure of special unit for IS/IT management of the organization.
Roadmap of IT implementation of IPB University

Diploma Program

The roadmap of IT implementation is shown in Table 4. The roadmap is based on the designed information system of IPB University Diploma Program. IT implementation is carried out in four stages, namely preparation, planning, stabilization, and implementation.

Tabel 6. Roadmap of IT implementation of IPB University Diploma Program

\begin{tabular}{lllll}
\cline { 2 - 4 } & \multicolumn{4}{c}{ Year } \\
\hline & 2018 & 2019 & 2020 & 2021 \\
\hline
\end{tabular}

Database and migration process architecture design

$1,2,3,4$

Academic application group

- IPB University Diploma Program Academic IS (main module of expertise program management, academic administration support data, curriculum, student data, general reports, student portal, lecturer portal, DIKTI reporting)

- IPB University Diploma Program Admission and Admission tests IS (main module of online registration, payment process, schedule arrangement, test location, test results management, results announcement)

- IPB University Diploma Program Student Registration IS (main module of registration data of new and old students)

- Graduation IS (Main module of graduation registration and information on the organization of graduation)

\section{Employment application group} Employment administration IS (major data collection of employee, employee history, and other functions related to the process of employment data management process )

\section{Financial application group}

Financial IS (main module of recording, management, and reports of financial budget allocation)

$\begin{array}{cc}1,2 & 3,4 \\ 1,2 & 3,4 \\ 1,2 & 3,4\end{array}$

Facilities and infrastructure application group

- Facilities and infrastructure IS (main module of physical assets owned by IPB University Diploma Program)

- Library IS (module of management of library asset, management of members, transactions)

$\begin{array}{lll}2 & 3 & 4\end{array}$

\section{Research and service application group} Research and community service IS(Main module of menegement of research and community service activities)

$1,2 \quad 3,4$




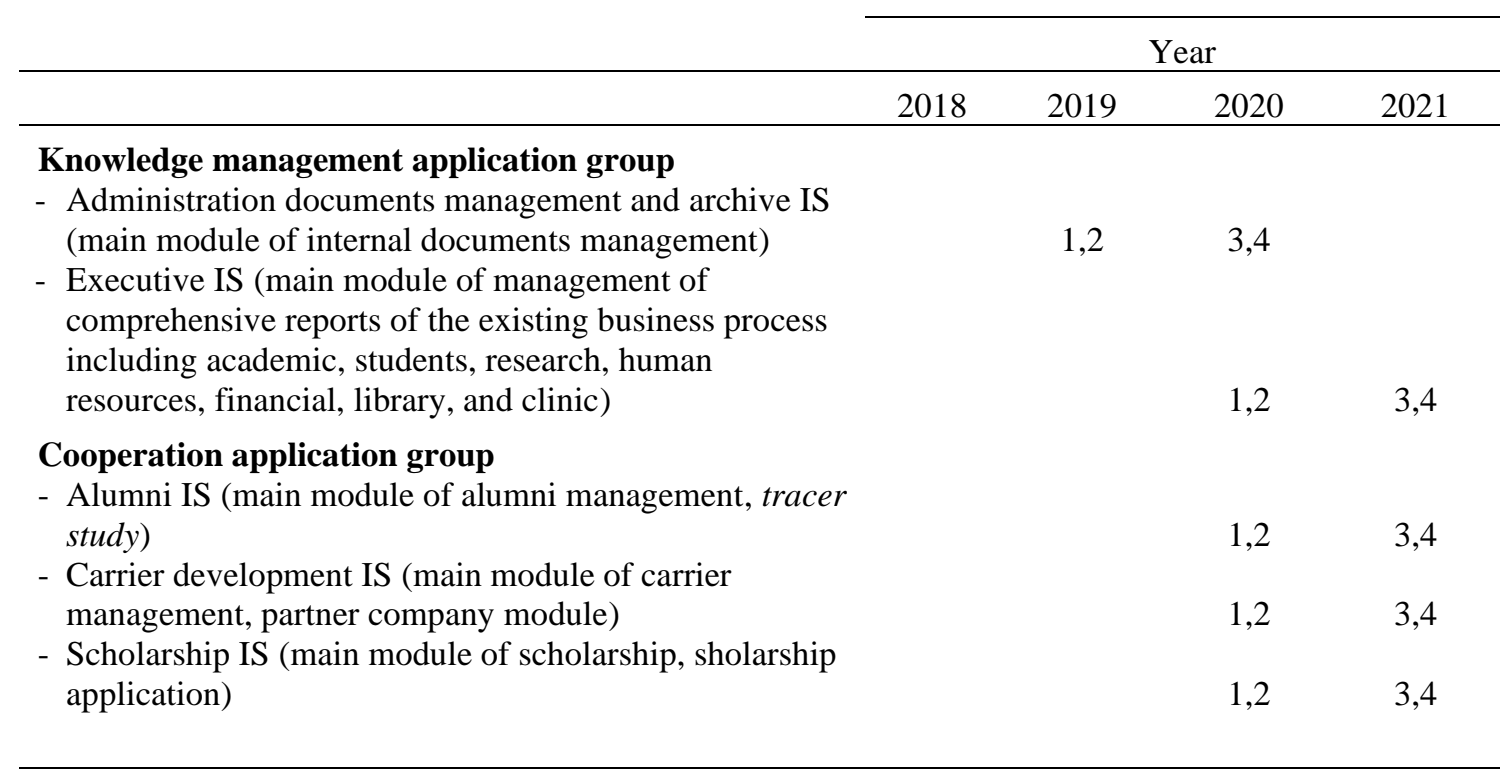

1. Preparation 2. Plannig 3. Stabilizing 4. implementation

\section{CONCLUSIONS}

The study on the information technology strategic plan of the IPB University Diploma Program resulted in recommendations of application portfolio, data and information architecture design, and information technology management strategy. In the application portfolio, there are 12 applications recommended to be developed and 5 existing applications recommended to be improved in order to provide maximum support to the IPB University Diploma Program business process.

In terms of information technology support infrastructure which consists of hardware and computer networks, the study suggests a modification of network architecture for data and information. The modification is aimed at better integration of developed applications to provide more optimum flow of data and information to meet stakeholders' data need.

Meanwhile, for the IPB University Diploma
Program IT management strategy, it is recommended that a special unit of information management be established to carry out the tasks of material collection, research, implementation, and evaluation of management of system, network, sites, information presentation, and periodical reports on the implementations of tasks. The unit is expected to be able to increase coordination with Central IPB IT management unit namely the DIDSI in improving the quality of information technology of the diploma program.

For further study, a detailed information technology architecture for IPB University Diploma Program needs to be designed as a technical reference for the implementation stage of the developed strategic plan. In addition to architecture design, it is also necessary to undertake an assessment on the maturity level of the IT implementation in the organization that can be used as a foundation for the development of IT quality in the organization. 


\section{ACKNOWLEDGMENT}

Authors are expressing their appreciation to all parties who have been supportive to the completion of this study. Authors also convey their appreciation to the IPB University Diploma Program for giving the opportunity to conduct this research. It is expected that this study would be beneficial.

\section{REFERENCES}

Chan YE, Reich BH. 2007. IT alignment: what have we learned? Journal of Information Technology 22 (4), 297-315 (2007)

[DIDSI] Direktorat Integrasi Data dan Sistem Informasi. Tersedia pada http://ict.ipb.ac.id/

[IPB] Institut Pertanian Bogor. 2013. Sistem Penjaminan Mutu Internal tahun 2013. Bogor. [Diploma IPB] Diploma Institut Pertanian Bogor. 2016. Panduan Pendidikan Program Diploma tahun 2016. Bogor.

[KMM] Kantor Manajemen Mutu. Tersedia pada http://kmm.ipb.ac.id/standar-mutu-ipb/spmidiploma/

Lukianto I, Lim C. 2011. Analysis Of Binus International University Information
Technology's Business Architecture.

Proceedings of The 1st International

Conference on Information Systems For

Business Competitiveness (ICISBC). 2011

Oktavia, L. dan Gaol, F. 2013. Information Technology Strategic Planning at PT. Venturium System. Journal of Computer Science. 9(12): 1847-1855.

Porter ME. 1998. Competitive Strategy Techniques For Analyzing Industries And Competitors. New York (NY): The Free Press.Setiawan A. 2012. Perencanaan Strategik Sistem Informasi pada Perusahaan Penerbitan dengan Metode Ward and Preppard: Studi Kasus pada Penerbit Rekayasa Sains Bandung. Jurnal Manajemen Teknologi. 11(3). 2012

Ward JM, Peppard J. 2002. Strategic Planning for Information Systems. $3^{\text {th }}$ ed. United Kingdom (UK): J Wiley.

Yunis R, Surendro. 2009. Model Enterprise Architecture Untuk Perguruan Tinggi Di Indonesia. semnasIF, 2009.Zhang Y, Zhang J, Chen J. 2013. Critical Success Factors in IT Service Management Implementation: People, Process, and Technology Perspectives. International Conference on Service Science. 